\title{
Prediction of phase equilibria in water-salt systems
}

\author{
(C) Evgeny S. Mironovich, ${ }^{+}$Alexander V. Kolyado, \\ Ivan K. Garkushin, ${ }^{*}$ and Evgeny A. Kleymenov \\ Department of General and Inorganic Chemistry. Samara State Technical University. \\ St. Molodogvardeiskaya, 244. Samara, 443100. Samara region. Russia. \\ Phone:+7 (846) 278-43-11.E-mail:e.mironovich@bk.ru
}

\begin{abstract}
*Supervising author; ${ }^{+}$Corresponding author
Keywords: phase equilibrium prediction, multicomponent systems, water-salt systems, potassium hydrogen phosphate, urea, liquid complex fertilizers.
\end{abstract}

\section{Abstract}

Produced review scientific and technical reference books on individual substances and the twocomponent systems forming part of the water-salt system $\mathrm{K}_{2} \mathrm{HPO}_{4}-\left(\mathrm{NH}_{2}\right)_{2} \mathrm{CO}-\mathrm{H}_{2} \mathrm{O}$. To predict phase equilibria in a real system, a mathematical model is proposed that allows one to determine the dependence of the activity coefficient of a substance or ion on the concentration and temperature of the solution. The solution of the system of equations was carried out in the environment of the table processor Microsoft Excel as a result, in terms of potassium hydrogen phosphate, the following characteristics of the eutectic alloy with the calculated content of components in the eutectic were obtained: $36.5 \%$ wt. $\mathrm{K}_{2} \mathrm{HPO}_{4}, 11.5 \%$ wt. $\left(\mathrm{NH}_{2}\right)_{2} \mathrm{CO}$, $52.0 \%$ wt. $\mathrm{H}_{2} \mathrm{O}$, melting point $250.6 \mathrm{~K}\left(-22.6^{\circ} \mathrm{C}\right)$. In order to search for a composition with a minimum crystallization temperature in the ternary urea - potassium hydrogen phosphate - water system, the simplex $\mathrm{K}_{2} \mathrm{HPO}_{4} \cdot 6 \mathrm{H}_{2} \mathrm{O}-\left(\mathrm{NH}_{2}\right)_{2}$ was studied $\mathrm{CO}-\mathrm{H}_{2} \mathrm{O}$ by visual polythermal method. The eutectic in the studied system crystallizes at a temperature of minus $28^{\circ} \mathrm{C}$ and contains $8 \%$ wt. carbamide, $35 \%$ wt. potassium hydrogen phosphate, $57 \%$ wt. water. An analysis of the data obtained by experimental and computational methods showed satisfactory convergence. The average deviation of the calculated data from the experimental ones was $18.9 \%$ in composition and $2.3 \%$ in terms of the eutectic melting point. The proposed calculation algorithm can be used to predict the characteristics of eutectics in ternary water - salt systems for planning the experiment.

\section{References}

[1] R.R. Garaev. Development and justification of the parameters of the device for the preparation and introduction of liquid complex fertilizers in the soil: PhD Tesis: 05.20.01. Ufa. 2017. (russian)

[2] A.O. Naloychenko, A.Zh. Atakanov. Fertilizer by liquid mineral fertilizers with irrigation water (fertigation). SIC Association - IWMI Project increasing water productivity at field level (1111B). Kyrgyz Research Institute of Irrigation (Kyrgyz. Institute of Irrigation). From the series "To Help Farmers and WUAs". 2009. No.5. 13p. (russian)

[3] D.A. Korenkov. Fertilizers, their properties and methods of use. Moscow: Kolos. 1982. (russian)

[4] E.A. Muravin. Agricultural chemistry: textbook. allowance for students of secondary schools. Moscow: Kolos. 2003. (russian)

[5] A.V. Baranenko, P.A. Kuznetsov, V.Yu. Zakharova, A.P. Tsoi. The use of substances with phase transitions for the accumulation of thermal energy. Scientific and Technical Newsletter technology, mechanics and optics. 2018. (russian)

[6] A.G. Dolesov, V.A. Chrysonidi, G.A. Dolesov. Heat storage compositions based on crystalline hydrates. Modern high technology. 2012. No.12. P.14-15. (russian)

[7] O.D. Efimov. Phase equilibria in water-salt cold storage systems: PhD Tesis: 02.00 .04 - Krasnodar. 2001. (russian)

[8] A.N. Kirgintsev, L.N. Trushnikova, V.G. Lavrentieva. Solubility of inorganic substances in water. Directory. Leningrad: Chemistry. 1972. 248p. (russian)

[9] A.T. Zotov. Urea. Moscow: "Goskhimizdat". 1963.175p. (russian)

[10] Database "Thermal constants of substances" http://www.chem.msu.su/cgi-bin/tkv.pl

[11] A quick reference to chemistry. Under the editorship of Kurylenko O.D. 1964. Kiev: The Naukova Dumka. 992p.

[12] I.K. Garkushin, I.M. Kondratyuk, G.E. Egortsev, M.A. Istomova. Theoretical and experimental research methods of multicomponent systems: textbook. allowance. Samara: Samar. state tech. un-t. 2012.125p. (russian) 